\title{
Micro-Raman Spectroscopy Assessment of Chemical Compounds of Mantle Clinopyroxenes
}

\author{
Anastasiya D. Kalugina ${ }^{1,2}$ and Dmitry A. Zedgenizov ${ }^{1,2, *(1)}$ \\ 1 Geology and Geophysics Department, Novosibirsk State University, 630090 Novosibirsk, Russia; \\ a.kalugina@g.nsu.ru \\ 2 V.S. Sobolev Institute of Geology and Mineralogy, Siberian Branch of Russian Academy of Science, \\ 630090 Novosibirsk, Russia \\ * Correspondence: zed@igm.nsc.ru; Tel.: +7-913-757-7112
}

Received: 18 November 2020; Accepted: 1 December 2020; Published: 2 December 2020

\begin{abstract}
The composition of clinopyroxenes is indicative for chemical and physical properties of mantle substrates. In this study, we present the results of Raman spectroscopy examination of clinopyroxene inclusions in natural diamonds $(n=51)$ and clinopyroxenes from mantle xenoliths of peridotites and eclogites from kimberlites $(n=28)$. The chemical composition of studied clinopyroxenes shows wide variations indicating their origin in different mantle lithologies. All clinopyroxenes have intense Raman modes corresponding to metal-oxygen translation $\left(\sim 300-500 \mathrm{~cm}^{-1}\right)$, stretching vibrations of bridging O-Si- $\mathrm{O}_{\mathrm{br}}\left(v_{11} \sim 670 \mathrm{~cm}^{-1}\right)$, and nonbridging atoms $\mathrm{O}-\mathrm{Si}-\mathrm{O}_{\mathrm{nbr}}\left(v_{16} \sim 1000 \mathrm{~cm}^{-1}\right)$. The peak position of the stretching vibration mode $\left(v_{11}\right)$ for the studied clinopyroxenes varies in a wide range $\left(23 \mathrm{~cm}^{-1}\right)$ and generally correlates with their chemical composition and reflects the diopside-jadeite heterovalent isomorphism. These correlations may be used for rough estimation of these compounds using the non-destructive Raman spectroscopy technique.
\end{abstract}

Keywords: clinopyroxene; Raman spectroscopy; diamond; peridotite; eclogite; mantle

\section{Introduction}

Mineral inclusions in natural diamonds carry important information about the chemical physical conditions of the Earth's mantle. The sources of mineral inclusions in diamonds can be divided into three common parageneses: peridotite, eclogite, and rare websterite types. The major inclusions of the peridotite associations are olivine (forsterite), orthopyroxene (enstatite), garnet (Cr-rich pyrope), Cr-spinel (chromite), clinopyroxene (Cr-diopside), and Fe-Ni-sulfides; eclogite associations are usually represented by garnet (pyrope-almandine-grossular), clinopyroxene (omphacite), quartz (coesite), and Fe-sulfides [1]. Websteritic inclusions are generally presented by clinopyroxene and orthopyroxene, which associate with garnet and olivine in some rare cases.

Clinopyroxenes of different parageneses are considerably diverse in their chemical composition. Peridotite clinopyroxenes are represented by $\mathrm{Cr}$-diopside with $\mathrm{Na}_{2} \mathrm{O}<6 \mathrm{wt} . \%, \mathrm{Cr}_{2} \mathrm{O}_{3}$ 0.6-2.4 wt.\%, and $\mathrm{Mg \#} \mathrm{0.92-0.94.} \mathrm{Eclogite} \mathrm{clinopyroxene} \mathrm{(omphacite)} \mathrm{has} \mathrm{a} \mathrm{jadeite} \mathrm{component} \mathrm{(} \mathrm{NaAl}\left[\mathrm{Si}_{2} \mathrm{O}_{6}\right]$ ) varying from $10 \%$ to $60 \%$ and $\mathrm{Cr}_{2} \mathrm{O}_{3}<0.4 \%$ and $\mathrm{Mg} \#<80 \%$ [2]. Peridotite and eclogite clinopyroxene inclusions can be distinguished by the borderline of the $\mathrm{Cr} \#(\mathrm{Cr} /(\mathrm{Cr}+\mathrm{Al}))$ molar ratio ranging from 0.07 to 0.10 (Figure 1a). Taylor and Neal (1989) subdivided eclogites by clinopyroxenes jadeite components into three groups: (1) group A eclogites (high-pressure igneous cumulates formed as dikes within the upper mantle) with low-jadeite clinopyroxenes; (2) group B eclogites with moderate-jadeite clinopyroxenes (metamorphic products of a subducted oceanic crustal protolith); and (3) group $\mathrm{C}$ eclogites (a relic of the Earth's primary differentiation shortly after accretion) with high-jadeite 
clinopyroxenes (Figure 1b) [3]. Websterite clinopyroxenes cannot be determined with certainty, and they are considered to be transitional in composition between clinopyroxenes of peridotite and eclogite.
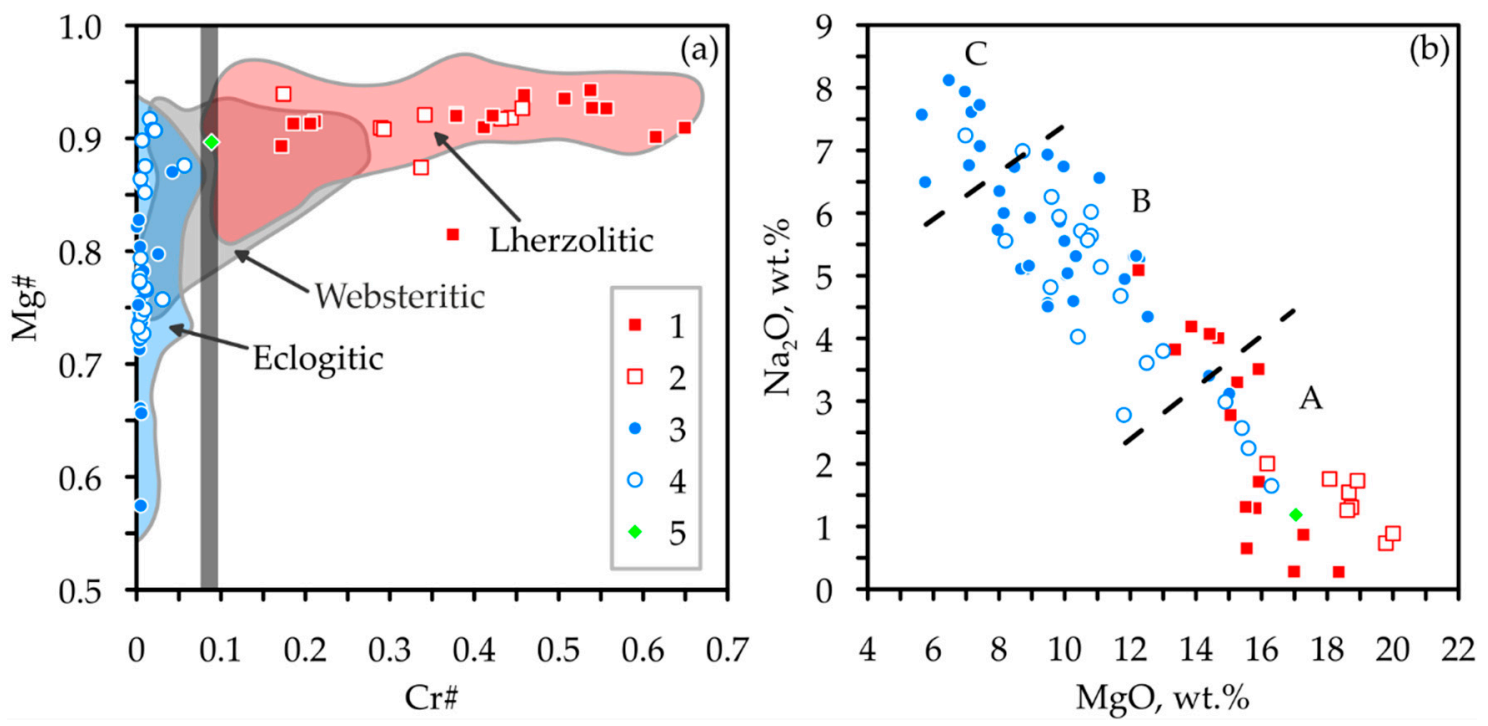

Figure 1. The discrimination of clinopyroxenes of different paragenesis: (a) Mg\# vs. Cr\# of clinopyroxenes-lherzolitic, websteritic, and eclogitic compositional fields and the transition from peridotite to eclogite clinopyroxenes at $\mathrm{Cr} \#$ 0.07-0.10 (gray vertical stripe) are taken from [2]; (b) $\mathrm{Na}_{2} \mathrm{O}$ vs. $\mathrm{MgO}$ contents in clinopyroxenes (A, B, C are the groups of eclogites are shown according to [3]). 1-peridotite clinopyroxene inclusions in diamonds, 2-clinopyroxenes from peridotites, 3 - eclogite clinopyroxene inclusions in diamonds, 4-clinopyroxenes from eclogites; 5-single clinopyroxene inclusion in diamond with transitional composition [2].

The analysis of the chemical composition of inclusions traditionally involves the partial destruction of the samples, e.g., study of the chemical composition of inclusions in diamonds by EPMA (electron probe microanalysis) requires specific sample preparation, such as polishing or crushing of the host. Therefore, the methods of study of mineral inclusions using non-destructive methods are becoming more demanded [4-9]. Raman spectroscopy is an alternative high-resolution non-invasive non-destructive technique, which provides information about specific vibrations in solid materials reflecting the chemical and structural features of minerals, including those presented as inclusions in natural diamonds. In this study, we present new data on the Raman spectroscopic characteristics of clinopyroxenes inclusions in natural diamonds and clinopyroxenes from the series of peridotite and eclogite xenoliths from kimberlite. These data are used to define the correlations between Raman features of mantle clinopyroxenes and their chemical composition.

\section{Materials and Methods}

In total, 51 natural diamonds were selected from different occurrences of Yakutian diamondiferous province (Internatsional'naya $(\mathrm{n}=9)$, Yubileynaya $(\mathrm{n}=4)$, Udachnaya $(\mathrm{n}=4)$, Mir $(\mathrm{n}=1)$, Komsomolskaya $(n=1)$, Nyurbinskaya $(n=2)$ kimberlite pipes, Ebelyakh river deposits $(n=30)$ ). The studied diamonds were represented by both octahedral and rounded dodecahedral crystals with the inclusions of peridotite or eclogite parageneses (Figure 2). The sample preparation includes polishing of a diamond parallel to the (110) plane in order to recover the inclusions to the surface for further analysis of chemical composition by EMPA. Some inclusions were examined by Raman spectroscopy before and after the polishing and several fully extracted inclusions from diamond were studied to avoid the ambiguity as clinopyroxene inclusions may be affected by the residual strain of a diamond host $[10,11]$. In total, 28 clinopyroxene grains were also selected from peridotite $(\mathrm{n}=8)$ and eclogite $(n=20)$ xenoliths from Udachnaya kimberlite pipe. The characterization of the clinopyroxenes from these samples is provided in $[12,13]$. 

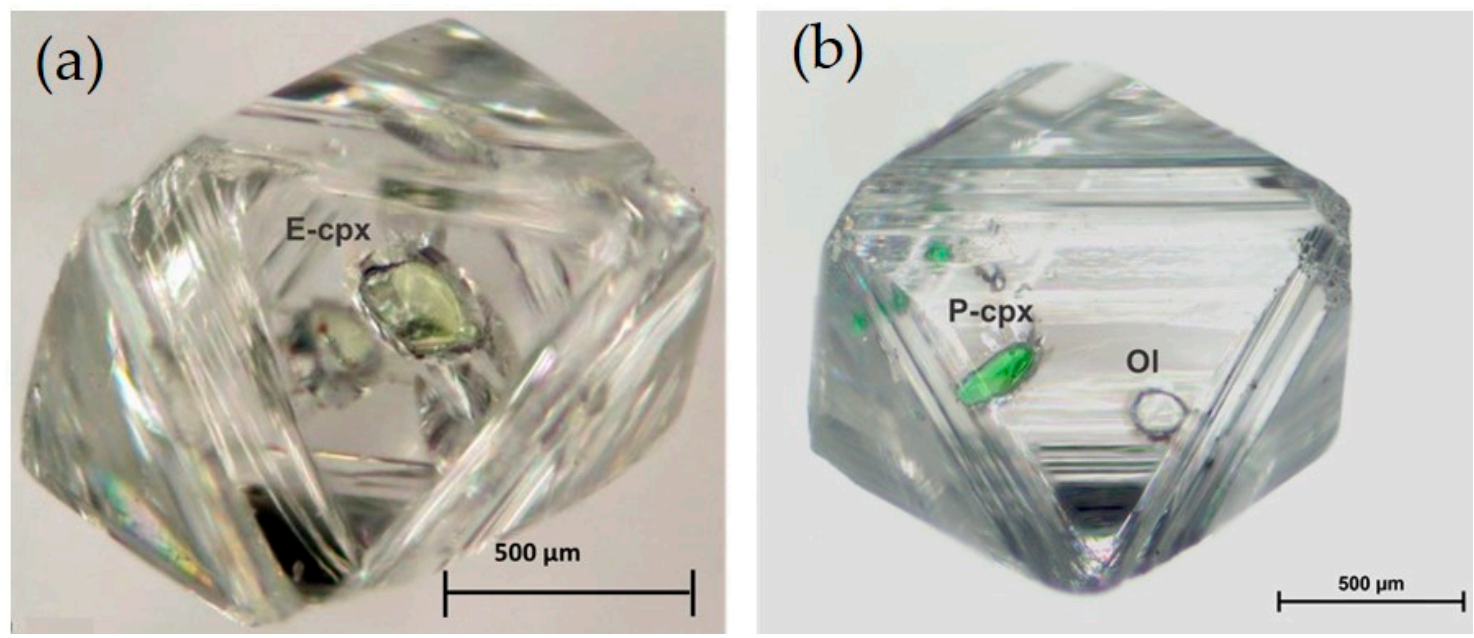

Figure 2. Two octahedral diamonds with (a) peridotite and (b) eclogite inclusion associations; E-cpx—eclogite clinopyroxene, $\mathrm{P}$-cpx-peridotite clinopyroxene, $\mathrm{Ol}$-olivine.

The chemical composition of the clinopyroxenes was determined on a JEOL JXA-8100 electron probe microanalyzer (EPMA), equipped with five wavelength-dispersive spectrometers and an energy-dispersive (EDX) spectrometer at an accelerating voltage of $20 \mathrm{kV}$ and probe current of $100 \mathrm{nA}$. The beam diameter was 1-3 $\mu \mathrm{m}$. The ZAF correction routine were applied. Natural standards were used: BD (diopside), O-145 (pyrope), Ud-92 (Cr-pyrope)—Lavrent'ev et al. (2015) [14]. The chemical composition of some clinopyroxene inclusion was taken from the published data (MT, HI- [15]; NBI-[16]; Ud10—[17]).

Raman spectra were collected using a Horiba Jobin Yvon LabRAM HR800 Raman microspectrometer with a multichannel air-cooled $\left(-70^{\circ} \mathrm{C}\right) \mathrm{CCD}$ detection system and a 532-nm Nd:YAG laser, equipped with an Olympus BX41 microscope $(\times 50)$. Spectra were recorded in back-scattering geometry in the range $100-1200 \mathrm{~cm}^{-1}$, through 7-10-s exposure and 10-15 acquisitions. The width of slit was $100 \mu \mathrm{m}$ and the power of the laser was $10 \mathrm{~mW}$. The spectra were calibrated using known emission lines of the Ne-lamp, also the Si-band at $520.6 \mathrm{~cm}^{-1}$ was used for monitoring of the frequencies of the Raman spectra. Additionally, the spectra were obtained at different crystallographic orientations via rotation (for each $15^{\circ}$ ) because some modes can change their intensity and disappear or are overlapped [18]. The spectroscopic software OPUS 8.2. (Bruker Optik GmbH, Ettlingen, Germany) was used for manipulation with spectra: the peak position was obtained by a regression least-squares curve fitting calculation using a Gaussian-Lorentzian mixed peak shape and baseline correction. This procedure yields a precision for peak of $\pm 0.5 \mathrm{~cm}^{-1}$.

\section{Results}

Most of the studied inclusions are presented by clinopyroxenes, which correspond to either peridotite $(n=16)$ or eclogite $(n=34)$ parageneses and single inclusion (Cr\# 0.08 and Mg\# 0.89) falls into the field of compositions transitional between these two principal parageneses (Figure 1a,b). The inclusions of peridotite clinopyroxene are $\mathrm{Cr}$-rich diopside $\left(\mathrm{Cr}_{2} \mathrm{O}_{3} 0.31-5.74 \mathrm{wt} . \%, \mathrm{CaO} 12.81-22.9 \mathrm{wt} . \%\right.$, $\mathrm{MgO} 12.25-18.3$ wt. $\%$ ) with relatively low $\mathrm{FeO} 1.81-3.45$ wt. $\%, \mathrm{Al}_{2} \mathrm{O}_{3}$ 0.31-5.41 wt.\%, and $\mathrm{Na}_{2} \mathrm{O}$ 0.28-5.09 wt.\%. They have relatively high Mg\# 0.87-0.94 and Cr\# 0.17-0.64. The inclusions of eclogite clinopyroxenes are omphacites $\left(\mathrm{Na}_{2} \mathrm{O} 3.12-8.12\right.$ wt.\%, $\mathrm{Al}_{2} \mathrm{O}_{3} 4.46-17.9$ wt.\%, $\mathrm{CaO} 9.81-17.2$ wt.\%, $\mathrm{MgO}$ 5.65-15.1 wt.\%, FeO 2.22-11.4 wt.\%). These clinopyroxenes have low $\mathrm{Cr}_{2} \mathrm{O}_{3}<0.3 \mathrm{wt} . \%$ and wide variation of $\mathrm{Mg} \#$ from 0.57 to 0.87 . Most studied clinopyroxene inclusions fall into the range of clinopyroxenes of groups B and C eclogites and rare inclusions correspond to clinopyroxenes of group A eclogites (Figure 1b) [3].

The clinopyroxenes from peridotites have a limited variation of composition ( $\mathrm{MgO} 16.2-20 \mathrm{wt} . \%$, FeO 1.92-4.62 wt.\%, $\mathrm{CaO} 17-20.7$ wt.\%, $\mathrm{Na}_{2} \mathrm{O} 2.01-7.01$ wt.\%, $\mathrm{Al}_{2} \mathrm{O}_{3}$ 0.82-2.71 wt.\%, $\mathrm{Cr}_{2} \mathrm{O}_{3}$ 0.80-1.21 wt.\%) with high $\mathrm{Mg} \#$ 0.87-0.94 and $\mathrm{Cr} \#$ 0.17-0.45. The clinopyroxenes from eclogites show wider compositional 
variations (MgO 6.98-15.6 wt.\%, FeO 1.41-7.16 wt.\%, $\mathrm{CaO} 10.6-20.3$ wt.\%, $\mathrm{Na}_{2} \mathrm{O} 2.25-7.24$ wt. $\%, \mathrm{Al}_{2} \mathrm{O}_{3}$ 3.37-15.3 wt.\%) with lower $\mathrm{Cr}_{2} \mathrm{O}_{3}$ content ( $\left.<0.3 \mathrm{wt} . \%\right)$ and $\mathrm{Mg \#} \mathrm{0.72-0.91.} \mathrm{Most} \mathrm{of} \mathrm{these} \mathrm{clinopyroxenes}$ from eclogites belong to group B $(n=14)$, four samples belong to group A and two belong to group C. All clinopyroxenes display positive sufficient correlations between $\mathrm{CaO}$ and $\mathrm{MgO}(\mathrm{r}=0.80)$ and between $\mathrm{Na}_{2} \mathrm{O}$ and $\mathrm{Al}_{2} \mathrm{O}_{3}(\mathrm{r}=0.94)$, and negative correlations between $\mathrm{CaO}$ and $\mathrm{Na}_{2} \mathrm{O}(\mathrm{r}=-0.92)$ and between $\mathrm{MgO}$ and $\mathrm{Al}_{2} \mathrm{O}_{3}(\mathrm{r}=-0.95)$. These correlations correspond to diopside-jadeite isomorphism in clinopyroxene (Table 1).

Table 1. The correlation coefficients for linear dependences between major elements and stretching vibration mode $\left(v_{11}\right)$ in clinopyroxenes (the bold are significant at $\alpha=10^{-4}$ ).

\begin{tabular}{cccccccccc}
\hline & $\mathrm{SiO}_{\mathbf{2}}$ & $\mathrm{TiO}_{\mathbf{2}}$ & $\mathrm{Al}_{\mathbf{2}} \mathrm{O}_{\mathbf{3}}$ & $\mathrm{Cr}_{\mathbf{2}} \mathrm{O}_{\mathbf{3}}$ & $\mathbf{F e O}$ & $\mathbf{M g O}$ & $\mathrm{CaO}$ & $\mathbf{N a}_{\mathbf{2}} \mathbf{O}$ & $\boldsymbol{v}_{\mathbf{1 1}}$ \\
\hline $\mathrm{SiO}_{2}$ & 1 & & & & & & & & \\
$\mathrm{TiO}_{2}$ & -0.06 & 1 & & & & & & & \\
$\mathrm{Al}_{2} \mathrm{O}_{3}$ & 0.27 & 0.48 & 1 & & & & & & \\
$\mathrm{Cr}_{2} \mathrm{O}_{3}$ & -0.11 & -0.32 & $-\mathbf{0 . 5 1}$ & 1 & & & & & \\
$\mathrm{FeO}$ & -0.40 & 0.36 & 0.33 & -0.49 & 1 & & & & \\
$\mathrm{MgO}$ & -0.09 & -0.51 & $\mathbf{- 0 . 9 5}$ & 0.42 & -0.45 & 1 & & & \\
$\mathrm{CaO}$ & -0.23 & -0.47 & $\mathbf{- 0 . 8 6}$ & 0.35 & $\mathbf{- 0 . 5 2}$ & $\mathbf{0 . 8 0}$ & 1 & & \\
$\mathrm{Na}_{2} \mathrm{O}$ & 0.19 & 0.50 & $\mathbf{0 . 9 4}$ & -0.37 & 0.42 & $\mathbf{- 0 . 9 4}$ & $\mathbf{- 0 . 9 2}$ & 1 & \\
$v_{11}$ & 0.27 & 0.42 & $\mathbf{0 . 9 7}$ & -0.48 & 0.36 & $\mathbf{- 0 . 9 2}$ & $\mathbf{- 0 . 8 8}$ & $\mathbf{0 . 9 5}$ & 1 \\
\hline
\end{tabular}

The structure of clinopyroxene is known to consist of $\mathrm{SiO}_{4}$-tetrahedra chains parallel to [001] linked by cation layers of $\mathrm{M} 1 \mathrm{O}_{6}$-octahedron and $\mathrm{M} 2 \mathrm{O}_{8}$-coordinated polyhedral. The factor group analysis of the clinopyroxene structure $(C 2 / c)$ defines 30 Raman active modes $\left(14 \mathrm{~A}_{\mathrm{g}}+16 \mathrm{~B}_{\mathrm{g}}\right)$ [19-23]. The Raman spectra of the studied clinopyroxenes generally exhibit several intense modes near $\sim 300-500$, 670, and $1000 \mathrm{~cm}^{-1}$ assigned to metal-oxygen translation, stretching vibrations of bridging $\mathrm{O}-\mathrm{Si}-\mathrm{O}_{\mathrm{br}}\left(v_{11}\right)$, and non-bridging atoms O-Si-O $\mathrm{O}_{\text {nbr }}\left(v_{16}\right)$, respectively (Figure 3$)$. Raman modes in the metal-oxygen translation range overlap and it is difficult to separate each peak by fitting. The O-Si-O $\mathrm{O}_{\text {nbr }}$ mode $\left(v_{16}\right)$ of clinopyroxenes shows the peak position shifting from 1010 to $1025 \mathrm{~cm}^{-1}$, which depends on the composition. The intensities of this mode depend on the crystal orientation, and the Raman shift (up to $7 \mathrm{~cm}^{-1}$ ) in different crystallographic orientations of single inclusion is possible. The peak positions of the stretching $\mathrm{O}-\mathrm{Si}-\mathrm{O}_{\mathrm{br}}$ mode vary in the range up to $23 \mathrm{~cm}^{-1}$ for the clinopyroxenes of different compositions $\left(665.6-675.5 \mathrm{~cm}^{-1}\right.$ for peridotite clinopyroxene inclusions and $673.8-688.2 \mathrm{~cm}^{-1}$ for eclogite clinopyroxene inclusions; $666.8-670.9 \mathrm{~cm}^{-1}$ for clinopyroxenes from peridotites and $671.5-687.2 \mathrm{~cm}^{-1}$ for clinopyroxenes from eclogites). This mode has only slight variations (always $<0.7 \mathrm{~cm}^{-1}$ ) in the different crystallographic orientations of the studied clinopyroxenes. The peak position frequencies of the stretching $\mathrm{O}-\mathrm{Si}-\mathrm{O}_{\mathrm{br}}$ mode for the studied clinopyroxene from the same inclusions in diamonds before and after polishing have discrepancies less than $0.79 \mathrm{~cm}^{-1}$ (Appendix A, Figure A1). Thus, the stretching $\mathrm{O}-\mathrm{Si}-\mathrm{O}_{\mathrm{br}}$ mode may be precisely fitted and seems to be most suitable for estimation of the possible dependencies with composition. 

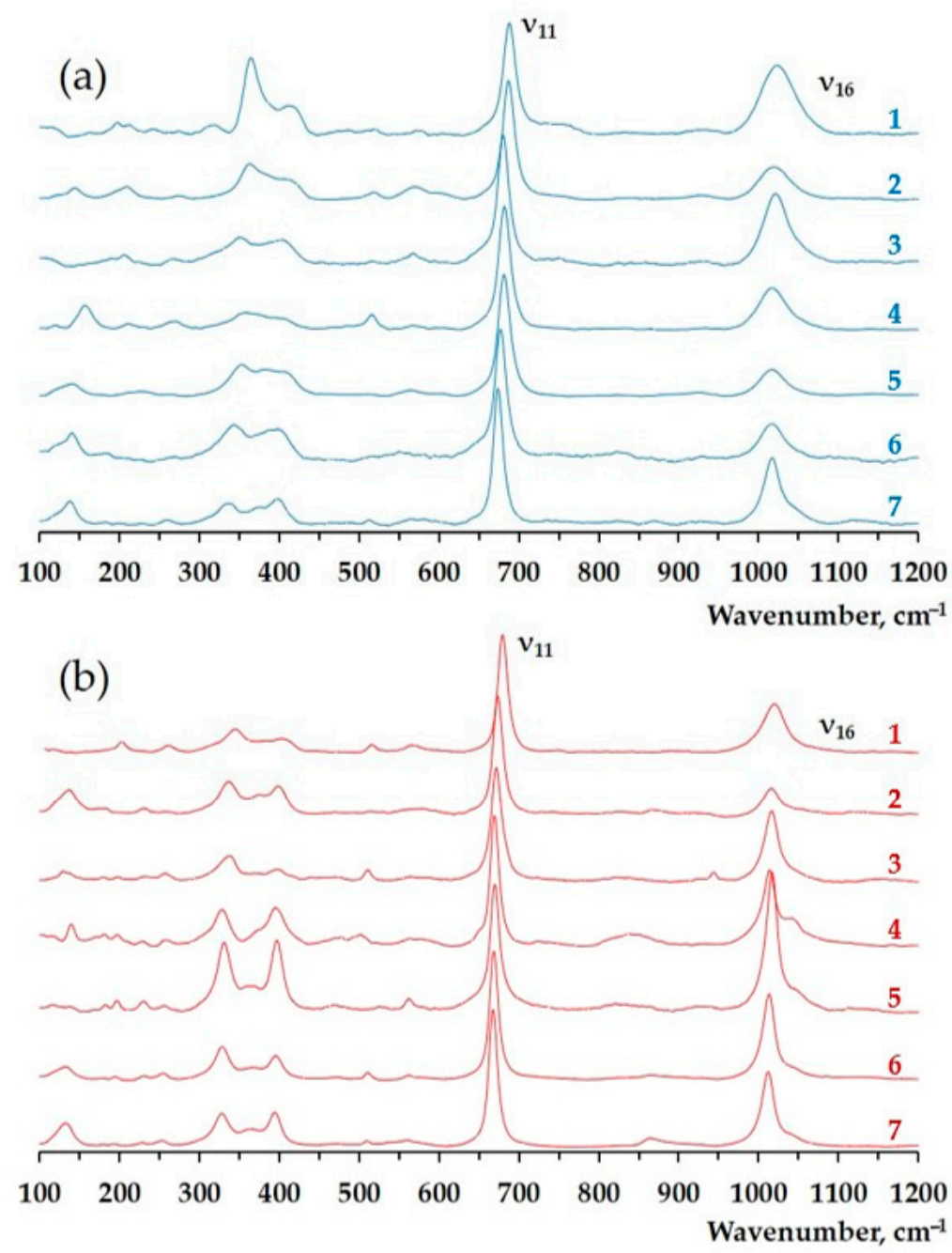

Figure 3. Raman spectra of clinopyroxenes of different parageneses: (a) Eclogite clinopyroxenes $(1,4,5$-inclusions in diamonds from Ebelyakh river deposits; 2,3,6,7-inclusions in diamonds from Internatsional'naya pipe); (b) peridotite clinopyroxenes (1-inclusion in diamond from Udachnaya pipe; 2-5-inclusions in diamonds from Internatsional'naya pipe; 6,7-clinopyroxenes from Udachnaya pipe). $v_{11}$-stretching bridging vibration mode $\mathrm{O}-\mathrm{Si}-\mathrm{O}_{\mathrm{br}}, v_{16}$-stretching non-bridging vibration mode $\mathrm{O}-\mathrm{Si}-\mathrm{O}_{\mathrm{nbr}}$.

\section{Discussion}

The elements can continuously substitute each other in the structure of clinopyroxene (e.g., diopside $\mathrm{CaMg}\left[\mathrm{Si}_{2} \mathrm{O}_{6}\right]$ —omphacite $\mathrm{Na}_{0.5} \mathrm{Ca}_{0.5} \mathrm{Mg}_{0.5} \mathrm{Al}_{0.5}\left[\mathrm{Si}_{2} \mathrm{O}_{6}\right]$ 一jadeite $\mathrm{NaAl}\left[\mathrm{Si}_{2} \mathrm{O}_{6}\right]$ join in eclogite clinopyroxenes and diopside $\mathrm{CaMg}\left[\mathrm{Si}_{2} \mathrm{O}_{6}\right]$ - cosmochlor $\mathrm{NaCr}\left[\mathrm{Si}_{2} \mathrm{O}_{6}\right]$ joins in peridotite clinopyroxenes) [24]. Isostructural substitutions of the cations influence the lengths and angles of bonds, which changes the energy of Si-O vibrations and, consequently, the wavenumbers of Raman peak positions. In clinopyroxenes, heterovalent isomorphism $\mathrm{Na}^{+} \mathrm{Al}^{3+}-\mathrm{Ca}^{2+} \mathrm{Mg}^{2+}$ affects Raman shifts close to linear [18]. These Raman shifts may be calibrated with the chemical composition of clinopyroxenes obtained by other techniques. It makes it possible to use the Raman technique for quantitative estimation of the contents of the major chemical compounds of this mineral.

We compared the peak position frequencies of the stretching $\mathrm{O}-\mathrm{Si}-\mathrm{O}_{\mathrm{br}}$ mode $\left(v_{11}\right)$ with the chemical composition of the studied clinopyroxenes. Large variations in the composition, accompanied by wide 
Raman shifts of the $v_{11}$ mode, allowed determination of adequate linear dependences and the regression parameters of these correlations. The correlation coefficients for all observed linear dependences for $\alpha$ (the level of significance or the probability of a type I error) $=10^{-4}$ are summarized in Table 1 . Several linear dependences between the Raman shift of the $v_{11}$ mode and content of some major elements were found. The most prominent are positive correlations with $\mathrm{Na}_{2} \mathrm{O}(\mathrm{r}=0.95)$ and $\mathrm{Al}_{2} \mathrm{O}_{3}(\mathrm{r}=0.97)$ contents and negative correlations with $\mathrm{CaO}(\mathrm{r}=-0.88)$ and $\mathrm{MgO}(\mathrm{r}=-0.92)$ contents. We did not observe any significant dependences with content of $\mathrm{Cr}_{2} \mathrm{O}_{3}$ and $\mathrm{FeO}$. It may be caused by the fact that $\mathrm{Fe}$ and $\mathrm{Cr}$ atoms of different valence can occupy different structural positions $\left(\mathrm{M} 2 \mathrm{O}_{8}\right.$ or $\left.\mathrm{M} \mathrm{O}_{6}\right)[25,26]$.

The observed dependences can be described as Deming regression equations as functions on Raman shift (significant at $\alpha=0.05$ ):

$$
\begin{gathered}
\mathrm{CaO}=-0.61( \pm 0.1) \times v_{11}+427.4( \pm 61.9) \\
\mathrm{MgO}=-0.71( \pm 0.08) \times v_{11}+493.9( \pm 59.1) \\
\mathrm{Na}_{2} \mathrm{O}=0.37( \pm 0.04) \times v_{11}-251.3( \pm 32.5) \\
\mathrm{Al}_{2} \mathrm{O}_{3}=0.81( \pm 0.05) \times v_{11}-545.2( \pm 37.2)
\end{gathered}
$$

where $\mathrm{Na}_{2} \mathrm{O}, \mathrm{Al}_{2} \mathrm{O}_{3}, \mathrm{CaO}, \mathrm{MgO}$ in wt. $\%$; $v_{11}$-frequency of the peak position of the O-Si-O $\mathrm{O}_{\mathrm{br}}$ Raman mode. The observed correlations and calculated regression lines are shown in Figure 4.
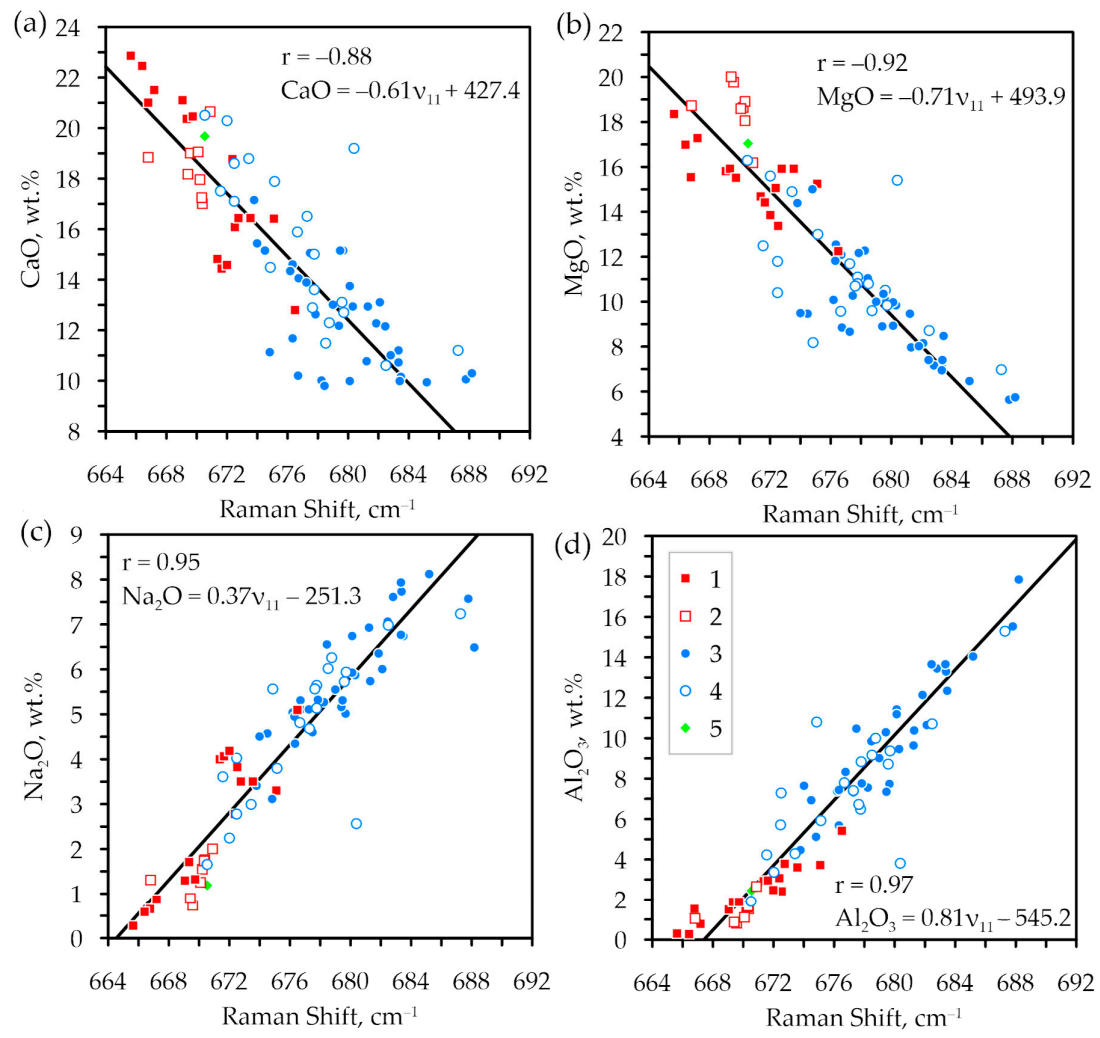

Figure 4. The correlation of the Raman shift of the frequency position of $\mathrm{O}-\mathrm{Si}-\mathrm{O}_{\mathrm{br}}$ mode $\left(v_{11}\right)$ in clinopyroxenes with contents of $\mathrm{CaO}(\mathbf{a}), \mathrm{MgO}(\mathbf{b}), \mathrm{Na}_{2} \mathrm{O}(\mathbf{c})$, and $\mathrm{Al}_{2} \mathrm{O}_{3}$ (d) determined from EPMA: 1-peridotite clinopyroxene inclusions in diamonds, 2-clinopyroxenes from peridotites, 3 - eclogite clinopyroxene inclusions in diamonds, 4-clinopyroxenes from eclogites; 5-single clinopyroxene inclusion in diamond with transitional composition [2]. The equations of Deming regression lines (1-4) are shown.

The data calculated from the regression equations and EPMA data yield sufficiently good convergence (Figure 5). Hereby, the equations of regression lines (1-4) can be used for a quantitative 
assessment of the chemical composition of mantle clinopyroxenes using only Raman spectroscopy technique. The discrepancies between Raman calculated data and EPMA data are $<5.0$ wt. $\%$ for $\mathrm{CaO}$ (mean 1.1 wt.\%), <4.2 wt.\% for $\mathrm{MgO}$ (mean 0.6 wt.\%), <2.5 wt.\% for $\mathrm{Na}_{2} \mathrm{O}$ (mean 0.4 wt. $\%$ ), and $<2.5 \mathrm{wt}$.\% for $\mathrm{Al}_{2} \mathrm{O}_{3}$ (mean $0.5 \mathrm{wt}$.\%). Some high discrepancies may occur because $\mathrm{Cr}_{2} \mathrm{O}_{3}$ and $\mathrm{FeO}$ were not considered in the calculations of the regression lines. It is known that strain pressure can also affect the Raman shifts of peak positions for anisotropic crystals [27]. However, the completely extracted and in situ inclusions of clinopyroxenes and clinopyroxenes from eclogites and peridotites give similar regression lines. It may suggest that the Raman shift of $\mathrm{v}_{11}$ stretching mode for clinopyroxene inclusions in diamonds depends on the composition rather than residual internal pressure.
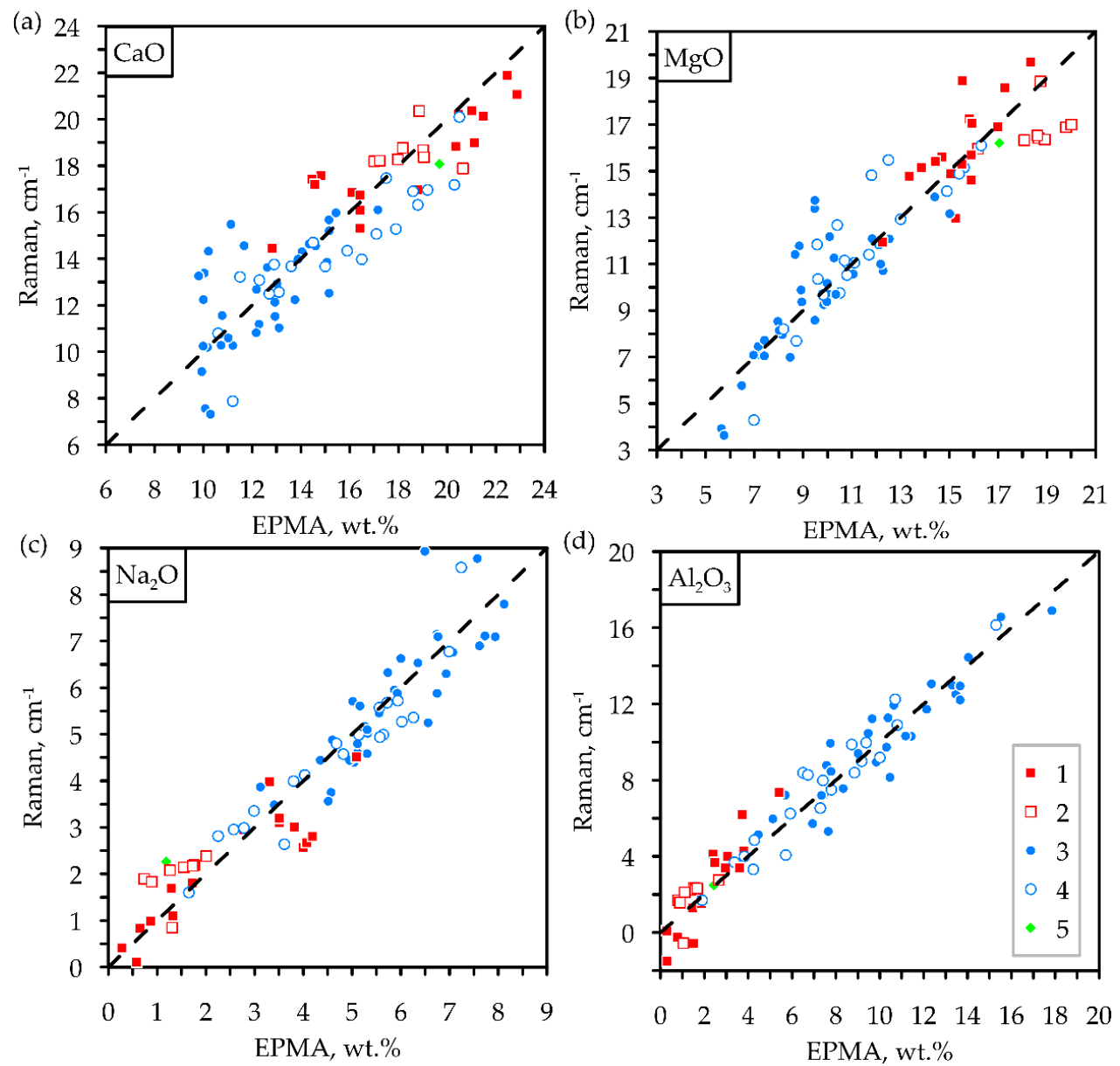

Figure 5. The convergence of $\mathrm{CaO}(\mathbf{a}), \mathrm{MgO}(\mathbf{b}), \mathrm{Na}_{2} \mathrm{O}(\mathbf{c})$, and $\mathrm{Al}_{2} \mathrm{O}_{3}$ (d) contents in clinopyroxenes determined by EPMA and calculated from Raman spectroscopy by using the parameters of the regression equations: 1 -peridotite clinopyroxene inclusions in diamonds, 2 -clinopyroxenes from peridotites, 3-eclogite clinopyroxene inclusions in diamonds, 4-clinopyroxenes from eclogites; 5-clinopyroxene inclusion in diamond with transitional composition [2]). The dashed line shows ideal convergence (EPMA = Raman).

The previously published data reveal that peridotite and eclogite clinopyroxenes can be discriminated by the Cr\# [1,2]. The lack of sufficient correlations of the stretching mode $v_{11}$ with the $\mathrm{Cr}$ and Fe contents do not allow assessment of these components using solely Raman data. It makes it difficult to discriminate the clinopyroxenes of different parageneses. Despite this, the clinopyroxenes of peridotite paragenesis and eclogite parageneses can roughly be separated by the peak position of the stretching $v_{11}$ mode. We calculated two separate distributions by the peak position of $v_{11}$ mode for peridotite and eclogite clinopyroxenes (Figure 6). These distributions are characterized by different parameters of the mean value and standard deviation $(\mu=670.2, \sigma=2.3$ for peridotite clinopyroxenes 
and $\mu=678.9, \sigma=4.0$ for eclogite clinopyroxenes), assuming that these distributions are normal. The Raman spectra of peridotite clinopyroxene has the stretching $v_{11}$ mode with a peak position frequency lower than $672 \mathrm{~cm}^{-1}$ with a probability of $85 \%(\alpha=0.15)$. Similarly, the clinopyroxene is likely to belong to eclogite (with probability of $85 \%, \alpha=0.15$ ) if the peak position of the stretching $v_{11}$ mode is higher than $675 \mathrm{~cm}^{-1}$. The uncertainty range takes place between 672 and $675 \mathrm{~cm}^{-1}$. This extended uncertainty range is due to the existence of $\mathrm{Na}_{2} \mathrm{O}$ rich with peridotite clinopyroxenes (4.19-5.09 wt.\%), which significantly overlap the range of eclogite clinopyroxenes and have the upshifted peak position of $v_{11}$ Raman mode. Some eclogite clinopyroxenes with relatively low $\mathrm{Na}_{2} \mathrm{O} \sim 2.25$ wt. $\%$ and elevated $\mathrm{Cr}_{2} \mathrm{O}_{3} \sim 0.27$ wt.\% also fall into the uncertainty range.

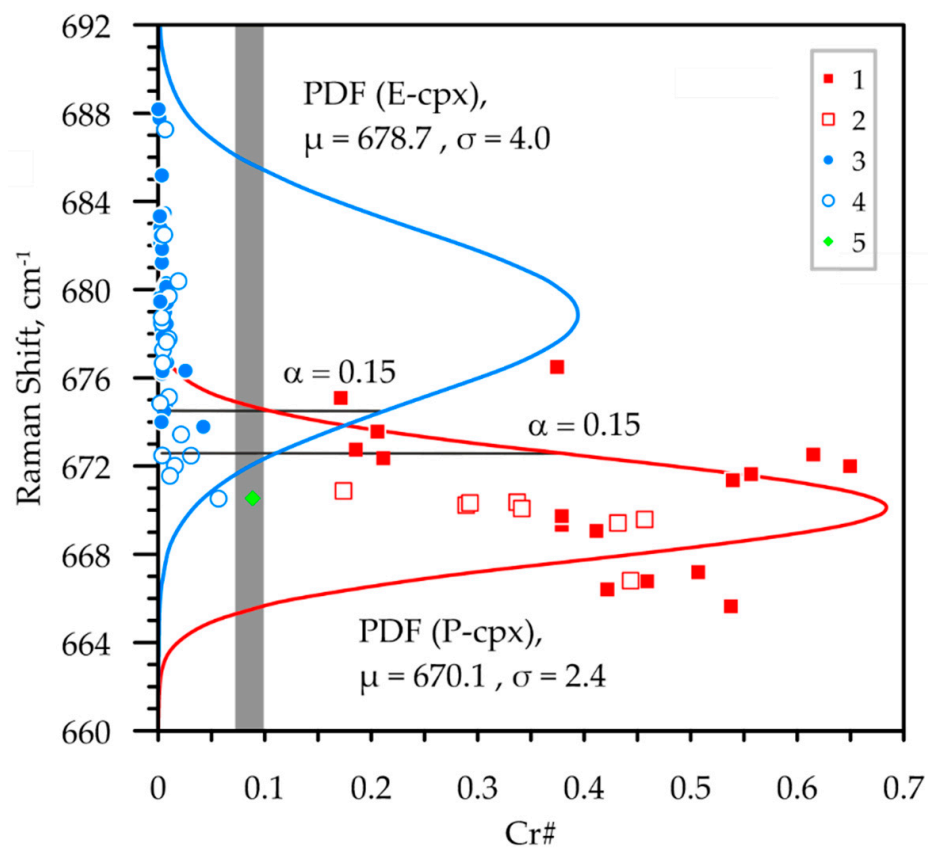

Figure 6. Raman shift of stretching mode $v_{11}$ vs. Cr\# of clinopyroxenes: 1 -peridotite clinopyroxene inclusions in diamonds, 2-clinopyroxenes from peridotites, 3-eclogite clinopyroxene inclusions in diamonds, 4-clinopyroxenes from eclogites; 5-clinopyroxene inclusion in diamond with transitional composition [2]. The transition from peridotite to eclogite clinopyroxenes occurs at the range $672-675 \mathrm{~cm}^{-1}$ of the peak position of $v_{11}$ mode; PDF-probability density function of normal distribution with parameters $\mu$ (mean) and $\sigma$ (standard deviation) for clinopyroxenes of peridotite (P-cpx) and eclogite (E-cpx) parageneses, $\alpha$-the level of significance for boundary lines of uncertainty area. The transition from peridotite to eclogite clinopyroxenes at Cr\# 0.07-0.10 is taken from [2].

\section{Conclusions}

Raman spectroscopy is a non-destructive technique for the identification of structural and chemical properties of minerals, and in particular is appropriate to study inclusions in natural diamonds. The new dataset of the Raman spectroscopic features of clinopyroxene inclusions in natural diamonds of different paragenesis (peridotite and eclogite) and clinopyroxenes from xenoliths peridotites and eclogites in kimberlite were obtained in this study. The wide variations of the peak position in a wide range for the $v_{11}$ mode of stretching vibrations of $\mathrm{Si}-\mathrm{O}-\mathrm{Si}_{\mathrm{br}}$ were found. These variations correlate well with the chemical composition of the studied clinopyroxenes. The correlations, described as linear regression lines, generally reflect heterovalent jadeite-diopside isomorphism and can potentially be applied to evaluate the chemical composition of mantle clinopyroxenes using only the Raman spectroscopy technique. The peak position of the stretching Si-O-Si $\mathrm{br}_{\mathrm{br}}$ Raman mode $\left(\mathrm{v}_{11}\right)$ can be satisfactorily used to separate clinopyroxenes of different parageneses. The clinopyroxenes with the peak position of $v_{11}$ mode lower than $672 \mathrm{~cm}^{-1}$ are likely to belong to peridotites; and the clinopyroxenes with the peak position of $\mathrm{v}_{11}$ mode higher than $675 \mathrm{~cm}^{-1}$ are likely to belong to eclogites. 
Author Contributions: A.D.K. and D.A.Z. equally contributed in this study. All authors have read and agreed to the published version of the manuscript.

Funding: The Raman spectroscopic study of clinopyroxenes and data processing was supported by Russian Science Foundation (16-17-10067). The sample preparation and study of chemical composition of clinopyroxenes was supported by Russian Science Foundation (18-17-00249).

Conflicts of Interest: The authors declare no conflict of interest.

\section{Appendix A}

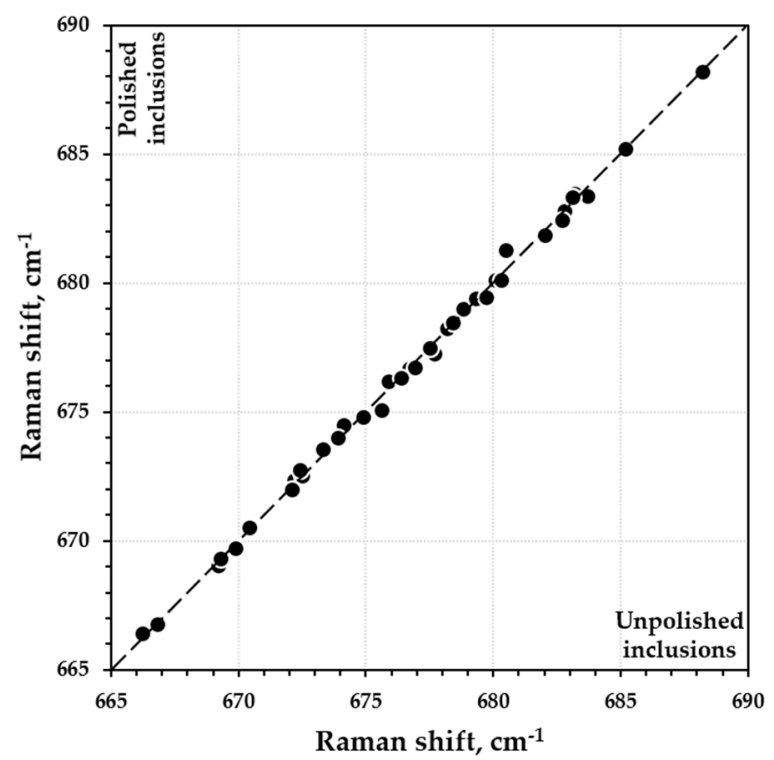

Figure A1. The convergence of the peak positions of stretching $\mathrm{Si}-\mathrm{O}-\mathrm{Si} \mathrm{i}_{\mathrm{br}}$ mode $\left(v_{11}\right)$ for clinopyroxene inclusions in studied diamonds before and after polishing.

\section{References}

1. Sobolev, N.V. Deep Inclusions in Kimberlites and the Problem of the Upper Mantle Composition; Sobolev, V.S., Ed.; Nauka: Moscow, Russia, 1974.

2. Stachel, T.; Harris, J.W. The origin of cratonic diamonds-Constraints from mineral inclusions. Ore Geol. Rev. 2008, 34, 5-32. [CrossRef]

3. Taylor, L.A.; Neal, C.R. Eclogites with oceanic crustal and mantle signatures from the Bellsbank kimberlite, South Africa, Part I: Mineralogy, petrography, and whole rock chemistry. J. Geol. 1989, 97, 551-567. [CrossRef]

4. Liu, L.G.; Mernagh, T.P.; Jaques, A.L. A mineralogical Raman spectroscopy study on eclogitic garnet inclusions in diamonds from Argyle. Contrib. Mineral. Petrol. 1990, 105, 156-161. [CrossRef]

5. Izraeli, E.S.; Harris, J.W.; Navon, O. Raman barometry of diamond formation. Earth Planet. Sci. Lett. 1990, 173, 351-360. [CrossRef]

6. McMillan, P. Theory and practice-lattice vibrations and spectroscopy of mantle phases. In Treatise on Geophysics; Price, D.G., Ed.; Elsevier: Amsterdam, The Netherlands, 2007; Volume 2, pp. 153-196.

7. Kagi, H.; Odake, S.; Fukura, S.; Zedgenizov, D.A. Raman spectroscopic estimation of depth of diamond origin: Technical developments and the application. Russ. Geol. Geophys. 2009, 50, 1183-1187. [CrossRef]

8. Nestola, F.; Alvaro, M.; Casati, M.N.; Wilhelm, H.; Kleppe, A.K.; Jephcoat, A.P.; Domeneghetti, M.C.; Harris, J.W. Source assemblage types for cratonic diamonds from X-ray synchrotron diffraction. Lithos 2016, 265, 334-338. [CrossRef]

9. Kalugina, A.D.; Zedgenizov, D.A. Raman discrimination of garnet inclusions in Siberian diamonds. J. Raman Spectrosc. 2020, 51, 1438-1444. [CrossRef]

10. Chopelas, A.; Serghiou, G. Spectroscopic evidence for pressure-induced phase transitions in diopside. Phys. Chem. Miner. 2002, 29, 403-408. [CrossRef] 
11. Lin, C.C. Pressure-induced polymorphism in enstatite $\left(\mathrm{MgSiO}_{3}\right)$ at room temperature: Clinoenstatite and orthoenstatite. J. Phys. Chem. Solids 2004, 65, 913-921. [CrossRef]

12. Kolesnichenko, M.V.; Zedgenizov, D.A.; Litasov, K.D.; Safonova, I.Y.; Ragozin, A.L. Heterogeneous distribution of water in the mantle beneath the central Siberian Craton: Implications from the Udachnaya Kimberlite Pipe. Gondwana Res. 2017, 47, 249-266. [CrossRef]

13. Kolesnichenko, M.V.; Zedgenizov, D.A.; Ragozin, A.L.; Litasov, K.D.; Shatsky, V.S. The role of eclogites in the redistribution of water in the subcontinental mantle of the Siberian craton: Results of determination of the water content in minerals from the Udachnaya pipe eclogites. Russ. Geol. Geophys. 2018, 59, 763-779. [CrossRef]

14. Lavrent'ev, Y.G.; Karmanov, N.S.; Usova, L.V. Electron probe microanalysis of minerals: Microanalyzer or scanning electron microscope? Russ. Geol. Geophys. 2015, 56, 1154-1161. [CrossRef]

15. Shatsky, V.S.; Zedgenizov, D.A.; Ragozin, A.L.; Kalinina, V.V. Diamondiferous subcontinental lithospheric mantle of the northeastern Siberian Craton: Evidence from mineral inclusions in alluvial diamonds. Gondwana Res. 2015, 28, 106-120. [CrossRef]

16. Zedgenizov, D.A.; Ragozin, A.L.; Kalinina, V.V.; Malkovets, V.G.; Pomazansky, B.S. Mineral inclusions in diamonds from Nyurbinskaya kimberlite pipe (Yakutia). In Geology and Mineral Resources of the North-East of Russia, Proceedings of Russian Scientific-Practical Conference "Geology and Mineral Resources of the North-East of Russia", Yakutsk, Russia, 31 March-2 April 2015; Biller, A.Y., Ed.; M.K. Ammosov North-Eastern Federal University: Yakutsk, Russia, 2015; pp. 173-176.

17. Gubanov, N.; Zedgenizov, D.; Sharygin, I.; Ragozin, A. Origin and evolution of high-Mg carbonatitic and low-Mg carbonatitic to silicic high-density fluids in coated diamonds from Udachnaya kimberlite pipe. Minerals 2019, 9, 734. [CrossRef]

18. Smith, D.C. The RAMANITA1@ method for non-destructive and in situ semi-quantitative chemical analysis of mineral solid-solutions by multidimensional calibration of Raman wavenumber shifts. Spectrochim. Acta A Mol. Biomol. Spectrosc. 2015, 61, 2299-2314. [CrossRef]

19. Wang, A.; Jolliff, B.L.; Haskin, L.A.; Kuebler, K.E.; Viskupic, K.M. Characterization and comparison of structural and compositional features of planetary quadrilateral pyroxenes by Raman spectroscopy. Am. Mineral. 2001, 86, 760-806. [CrossRef]

20. Mernagh, T.P.; Hoatson, D.M. Raman Spectroscopic Study of Pyroxene Structures from the Layered Intrusion, Munni Munni Western Australia. J. Raman Spectrosc. 1997, 28, 647-658. [CrossRef]

21. Chopelas, A. Estimates of mantle relevant Clapeyron slopes in the MgSiO3 system from high-pressure spectroscopic data. Am. Mineral. 1999, 84, 233-244. [CrossRef]

22. Huang, E.; Chen, C.H.; Huang, T.; Lin, E.H.; Xu, J.A. Raman spectroscopic characteristics of $\mathrm{Mg}-\mathrm{Fe}-\mathrm{Ca}$ pyroxenes. Am. Mineral. 2000, 85, 473-479. [CrossRef]

23. Prencipe, M.; Maschio, L.; Kirtman, B.; Salustro, S.; Erba, A.; Dovesi, R. Raman spectrum of $\mathrm{NaAlSi}_{2} \mathrm{O}_{6}$ jadeite. A quantum mechanical simulation. J. Raman Spectrosc. 2014, 45, 703-709. [CrossRef]

24. Deer, W.A.; Howie, R.A.; Zussman, J. Pyroxene Group. In An Introduction to the Rock-Forming Minerals, 2nd ed.; Longman Scientific \& Technical: London, UK, 1992.

25. Safonov, O.G.; Litvin, Y.A.; Perchuk, L.L. Synthesis of omphacites and isomorphic features of clinopyroxenes in the system $\mathrm{CaMgSi}_{2} \mathrm{O}_{6}-\mathrm{NaAlSi}_{2} \mathrm{O}_{6}-\mathrm{KAlSi}_{2} \mathrm{O}_{6}$. Petrology. 2004, 12, 84-97.

26. Papike, J.J.; Karner, J.M.; Shearer, C.K. Comparative planetary mineralogy: Valence state partitioning of $\mathrm{Cr}$, $\mathrm{Fe}$, $\mathrm{Ti}$, and $\mathrm{V}$ among crystallographic sites in olivine, pyroxene, and spinel from planetary basalts. Am. Mineral. 2005, 90, 277-290. [CrossRef]

27. Compomenosi, N.; Mazzucchelli, M.L.; Mihailova, B.; Scambelluri, M.; Angel, R.J.; Nestola, F.; Reali, A.; Alvaro, M. How geometry and anisotropy affect residual strain in host-inclusion systems: Coupling experimental and numerical approaches. Am. Mineral. 2018, 103, 2032-2035. [CrossRef]

Publisher's Note: MDPI stays neutral with regard to jurisdictional claims in published maps and institutional affiliations. 